Check for updates

Cite this: RSC Adv., 2019, 9, 15151

\title{
New transition metal complexes with a pendent indole ring: insights into the antifungal activity and mode of action $\uparrow$
}

\author{
Ovas Ahmad Dar, ${ }^{\text {a }}$ Shabir Ahmad Lone, ${ }^{\text {b }}$ Manzoor Ahmad Malik, ${ }^{a}$ \\ Mohmmad Younus Wani, (D) ${ }^{c}$ Aijaz Ahmad (D) *bd and Athar Adil Hashmi*a
}

\begin{abstract}
Development of new chemotherapeutic agents to treat multidrug-resistant fungal infections to augment the current treatment options is a must. In this direction, a series of mixed ligand complexes was synthesized from a Schiff base (L) obtained by the condensation of 2-hydroxynapthaldehyde and tryptamine, and 1,10-phenanthroline (1,10-phen) as a secondary ligand. Based on spectral characterization and physical measurements an octahedral geometry was assigned to [Co(phen) $\mathrm{LClH}_{2} \mathrm{O}$ ] (C2), [Ni(phen) $\left.\mathrm{LClH}_{2} \mathrm{O}\right](\mathrm{C} 3)$, and $\left[\mathrm{Zn}\left(\right.\right.$ phen) $\left.\mathrm{LClH}_{2} \mathrm{O}\right](\mathrm{C} 4)$ complexes while a distorted octahedral geometry was assigned to the $\left[\mathrm{Cu}(\right.$ phen $\left.) \mathrm{LClH}_{2} \mathrm{O}\right](\mathrm{C} 1)$ complex. All the synthesized compounds were tested for antifungal activity against 11 Candida albicans isolates, including fluconazole (FLC) resistant isolates, by determining minimum inhibitory concentrations and studying growth curves. MIC results suggest that all the newly synthesized compounds have potent antifungal activity at varying levels. The rapid action of these compounds on fungal cells suggested a membrane-located target for their action.
\end{abstract}

Received 7th April 2019

Accepted 30th April 2019

DOI: $10.1039 / c 9 r a 02600 b$

rsc.li/rsc-advances chemistry and medicine. ${ }^{9}$ Due to their astonishing structural properties and varied denticities, Schiff bases have received considerable attention for many years and these properties have resulted in their wide application in the clinical, biological, analytical and pharmaceutical fields. ${ }^{\mathbf{1 0 - 1 3}}$ The coordination of transition metals to these scaffolds increases their biological activities and lowers the cytotoxicity of both metal and the ligand. ${ }^{\mathbf{1 4 - 1 6}}$ Schiff base metal complexes are gaining considerable attention due to their potential antifungal, antitumor and antibacterial activities. ${ }^{17-20}$ Use of labile and auxiliary ligands like 1,10-phenenthroline, 2,2-bipyridyl, imidazole, and pyridine, on the other hand, have been demonstrated to show interesting biological profile with excellent antibacterial, antitumor, antiviral and antifungal activities already reported..$^{21-25} \mathrm{~A}$ good number of mixed ligand complexes containing 1,10-phenanthroline as a ligand are identified as potential chemotherapeutic agents and have received much attention in the field of medicine. ${ }^{26-29}$

In view of the promising biological activities of these scaffolds our main intention was to explore whether the incorporation of these important scaffolds in one complex would result in potentiation of activities and therefore would give a new strategy for the development of chemotherapeutic agents. Finding rare instances of literature about the tryptamine based Schiff base ligands and their mixed ligand complexes with 1,10phenenthroline, bearing an indole ring pendent, we report the synthesis, characterization and antifungal activity of the ligand and its metal complexes. Insight studies into the mechanism of action were done by studying their effect on $\mathrm{H}^{+}$-ATPase pump, 
a promising target to develop new antifungal drugs because of its important role in fungal cell physiology to maintain electrochemical proton gradient which in turn is important for nutrient uptake. In addition, this enzyme also plays a crucial role to regulate intracellular $\mathrm{pH}$ and maintains cell growth. The enzyme has also been reported to play role in the pathogenicity of Candida by regulating the pathogenicity markers such as morphological transition and secretion of hydrolytic enzymes.

\section{Experimental}

\subsection{Materials and methods}

All the reagents and chemicals used for the synthesis were of analytical grade and were purchased from commercial sources. They were used as received without further purification. Tryptamine and 2-hydroxynepthaldehyde were purchased from Sigma Aldrich. 1,10-Phenanthroline and metal chlorides were purchased from Merck.

Microanalyses (C, H and N) was carried out with FlashEA 1112 elemental analyzer (Thermo Scientific). The molar conductance at room temperature were measured on a Syntronics type 302 conductivity bridge equilibrated at $25 \pm$ $0.01{ }^{\circ} \mathrm{C}$. For conductivity measurements one millimolar solutions in DMSO were prepared. Electrothermal melting point apparatus was used to determine the melting point of the synthesized compounds. FT-IR spectra of the synthesized compounds were recorded using $\mathrm{KBr}$ pellets on a Perkin-Elmer 283 spectrophotometer. For ${ }^{1} \mathrm{H}$ NMR and ${ }^{13} \mathrm{C}$ NMR measurements Brucker WH 300 (200 MHz) and Brucker WH 270 (67.93 $\mathrm{MHz}$ ) were used using $\mathrm{CDCl}_{3}$ or DMSO- $d_{6}$ as a solvent and trimethylsilane as an internal standard. ESI-MS (AB-Sciex 2000, Applied Biosystem) was used to record mass spectra of the synthesized ligand and complexes.

\subsection{Synthesis}

2.2.1 Synthesis of Schiff base ligand (L). The Schiff base ligand, $(E)-1-(((2-(1 H$-indol-3-yl)ethyl)imino)methyl)naphthalen2-ol (L) was synthesized from the condensation reaction of 2hydroxynepthaldehyde $(0.86 \mathrm{~g}, 5 \mathrm{mmol})$ and tryptamine $(0.8 \mathrm{~g}, 5$ $\mathrm{mmol})$ in ethanol $(15 \mathrm{~mL})$ at room temperature for $3 \mathrm{~h}$. The reaction was monitored by taking TLC at regular intervals. The reaction mixture was kept overnight at room temperature and the bright yellow solid product formed was filtered, washed with least amount of ethanol and diethyl ether several times and then dried in vacuo over $\mathrm{CaCl}_{2}$ for further use.

Color (yellow) yield: $82 \%$. mp $192{ }^{\circ} \mathrm{C}$; elemental anal. calc. for $\mathrm{C}_{21} \mathrm{H}_{18} \mathrm{~N}_{2} \mathrm{O}: \mathrm{C}, 80.23 ; \mathrm{H}, 5.77 ; \mathrm{N} ; 8.91$; found: C, 79.57; $\mathrm{H}$, 5.69; N, 9.46; IR (KBr Pellet, $\left.\mathrm{cm}^{-1}\right)$ : $1618 \nu(-\mathrm{CH}=\mathrm{N}-), 3152$ $\nu(\mathrm{OH}), 1264 \nu(\mathrm{C}-\mathrm{O}), 3334 \nu(\mathrm{NH}),{ }^{1} \mathrm{H}$ NMR $\left(\mathrm{CDCl}_{3}, \delta, \mathrm{ppm}\right) 8.25$ $(\mathrm{s}, 1 \mathrm{H}, \mathrm{NH}), 8.42(\mathrm{~s}, 1 \mathrm{H}, \mathrm{CH}=\mathrm{N}), 14.2(\mathrm{~s}, 1 \mathrm{H}, \mathrm{OH}), 3.18(\mathrm{t}, 2 \mathrm{H}$, $\mathrm{CCH}_{2}$ ), 3.89 (t, 2H, $\mathrm{NCH}_{2}$ ), 6.86-7.65 (m, 11H, ArH). ${ }^{13} \mathrm{C}$ NMR $\left(\mathrm{CDCl}_{3}, \delta, \mathrm{ppm}\right): 171.22(\mathrm{C}-\mathrm{O}), 163.44(\mathrm{C}=\mathrm{N}), 58.25(\mathrm{C}-\mathrm{N}), 27.37$ $\left(\mathrm{CH}_{2}-\mathrm{C}\right.$ ), 111.99-138 (Ar C's), mass spectrum (ESI) $[\mathrm{M}+\mathrm{H}]^{+}=$ 315.0.

2.2.2 Synthesis of mixed ligand complexes (C1-C4). All the complexes were prepared by the general procedure as shown in

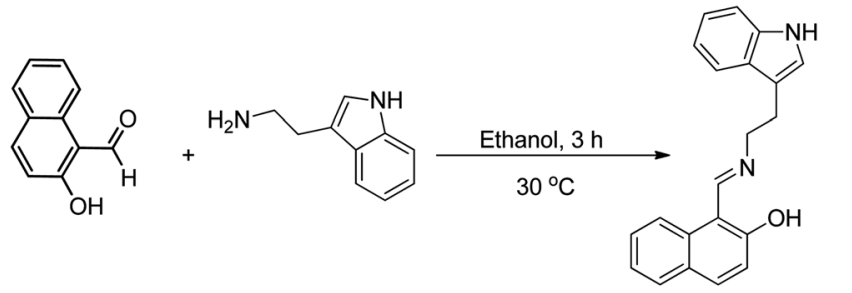

(L)

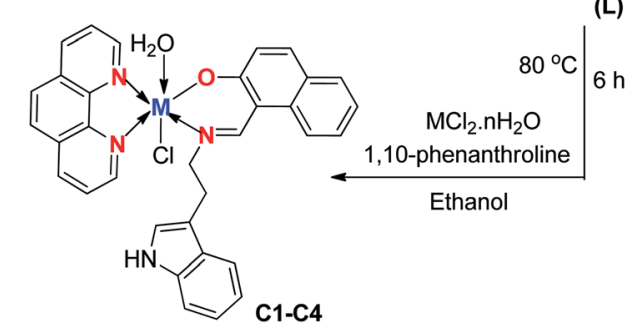

Where $\mathrm{M}=\mathrm{Cu}(\mathrm{II}), \mathrm{Co}(\mathrm{II}), \mathrm{Ni}(\mathrm{II})$ and $\mathrm{Zn}(\mathrm{II})$

Scheme 1 Synthesis of Schiff base (L) and mixed ligand complexes (C1-C4).

Scheme 1. To an ethanolic solution of the Schiff base $(0.62 \mathrm{~g}, 2$ mmol) was added an ethanolic solution of $\left[\mathrm{M}(\mathrm{Cl})_{2} \cdot n \mathrm{H}_{2} \mathrm{O}\right](2$ $\mathrm{mmol})$ dropwise and then triethylamine $(280 \mu \mathrm{L})$ with constant stirring. A few minutes later an ethanolic solution of 1,10-phen ( $0.36 \mathrm{~g}, 2 \mathrm{mmol}$ ) was added dropwise. The reaction mixture was refluxed for 4-6 h. The resultant product formed was washed several times with ethanol and diethyl ether, and then dried in vacuum over fused calcium chloride.

2.2.2.1 [Cu(phen) $\left.\mathrm{LClH}_{2} \mathrm{O}\right]$ (C1). Color (yellow green) yield: $68 \%$; mp: $252{ }^{\circ} \mathrm{C}$; elemental anal. calc. for $\left(\mathrm{C}_{33} \mathrm{H}_{27} \mathrm{ClCuN}_{4} \mathrm{O}_{2}\right): \mathrm{C}$, 64.91; H, 4.46; N, 9.18; found: C, 64.72; H, 4.87; N, 9.28; IR ( $\mathrm{KBr}$ pellet, $\left.\mathrm{cm}^{-1}\right): 1582 \nu(\mathrm{CH}=\mathrm{N}), 1289 \nu\left(\mathrm{C}-\mathrm{O}_{\text {phenol }}\right), 1178 \nu\left(\mathrm{C}-\mathrm{N}_{1,10-}\right.$ phen $), 3310 \nu(\mathrm{N}-\mathrm{H}), 735 \delta\left(\mathrm{C}=\mathrm{N}_{1,10 \text {-phen }}\right), 3505 \nu(\mathrm{OH}), 520 \nu(\mathrm{Cu}-$ O), $478 \nu(\mathrm{Cu}-\mathrm{N})$. Mass spectrum (ESI) $[\mathrm{M}+\mathrm{H}]^{+}=609.5$.

2.2.2.2 $\left[\mathrm{Co}(\right.$ phen $\left.) \mathrm{LClH}_{2} \mathrm{O}\right](\mathrm{C2})$. Color (brown) yield: $65 \%$. mp: $242{ }^{\circ} \mathrm{C}$; elemental anal. calc. for $\left[\mathrm{C}_{33} \mathrm{H}_{27} \mathrm{ClCoN}_{4} \mathrm{O}_{2}\right]: \mathrm{C}$, 65.41; H, 4.49; N, 9.25; found: C, 65.20; H, 4.37; N, 9.18; IR ( $\mathrm{KBr}$ pellet, $\left.\mathrm{cm}^{-1}\right): 1585 \nu(\mathrm{CH}=\mathrm{N}), 1289 \nu\left(\mathrm{C}-\mathrm{O}_{\text {phenol }}\right), 1170 \nu\left(\mathrm{C}-\mathrm{N}_{1,10-}\right.$ phen $), 3320 \nu(\mathrm{N}-\mathrm{H}), 728 \delta\left(\mathrm{C}=\mathrm{N}_{1,10-p h e n}\right), 3510 \nu(\mathrm{OH}), 527 \nu(\mathrm{Co}-$ O), $476 \nu(\mathrm{Co}-\mathrm{N})$. Mass spectrum (ESI) $[\mathrm{M}+\mathrm{H}]^{+}=605.9$.

2.2.2.3 [Ni(phen) $\left.\mathrm{LClH}_{2} \mathrm{O}\right](\mathrm{C3})$. Color (reddish brown) yield: $69 \%$; mp: $220{ }^{\circ} \mathrm{C}$; elemental anal. calc. for $\left[\mathrm{C}_{33} \mathrm{H}_{27} \mathrm{ClN}_{4} \mathrm{NiO}_{2}\right]: \mathrm{C}$, 65.43; H, 4.49; N, 9.25; found: C, 65.39; H, 4.52; N, 9.17; IR ( $\mathrm{KBr}$ pellet, $\left.\mathrm{cm}^{-1}\right): 1585 \nu(\mathrm{CH}=\mathrm{N}), 1286 \nu\left(\mathrm{C}-\mathrm{O}_{\text {phenol }}\right), 1178 \nu\left(\mathrm{C}-\mathrm{N}_{1,10}\right.$ phen $), 3304 \nu(\mathrm{N}-\mathrm{H}), 3508 \nu(\mathrm{OH}), 730 \delta\left(\mathrm{C}=\mathrm{N}_{1,10-p h e n}\right), 524 \nu(\mathrm{Ni}-\mathrm{O})$, $478 \nu(\mathrm{Ni}-\mathrm{N})$. Mass spectrum (ESI) $[\mathrm{M}+\mathrm{H}]^{+}=605.5$.

2.2.2.4 [ $\mathrm{Zn}($ phen $\left.) \mathrm{LClH}_{2} \mathrm{O}\right](\mathbf{C 4})$. Color (beige) yield: 70\%; mp: $222{ }^{\circ} \mathrm{C}$; elemental anal. calc. for $\left[\mathrm{C}_{33} \mathrm{H}_{27} \mathrm{ClN}_{4} \mathrm{O}_{2} \mathrm{Zn}\right]$ : $\mathrm{C}, 64.71 ; \mathrm{H}$, 4.43; N, 9.15; found: C, 64.52; H, 4.88; N, 9.10; IR ( $\mathrm{KBr}$ pellet, $\left.\mathrm{cm}^{-1}\right): 1590 \nu(\mathrm{CH}=\mathrm{N}), 1288 \nu\left(\mathrm{C}-\mathrm{O}_{\text {phenol }}\right), 1176 \nu\left(\mathrm{C}-\mathrm{N}_{1,10-}\right.$ phen $), 3312 \nu(\mathrm{N}-\mathrm{H}), 729 \delta\left(\mathrm{C}=\mathrm{N}_{1,10-p h e n}\right), 3507 \nu(\mathrm{OH}), 530 \nu(\mathrm{Zn}-$ O), $480 \nu(\mathrm{Zn}-\mathrm{N}) .{ }^{1} \mathrm{H}$ NMR (DMSO- $\left.d_{6}, \delta, \mathrm{ppm}\right), 10.75$ (s, $\left.1 \mathrm{H}, \mathrm{NH}\right)$,

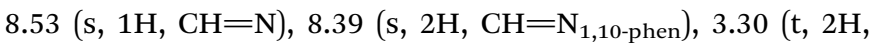
$\left.\mathrm{CCH}_{2}\right), 3.92\left(\mathrm{t}, 2 \mathrm{H}, \mathrm{NCH}_{2}\right), 3.57\left(\mathrm{~s}, 2 \mathrm{H}, \mathrm{H}_{2} \mathrm{O}\right), 6.51-8.19(\mathrm{~m}, 18 \mathrm{H}$, ArH). ${ }^{13} \mathrm{C}$ NMR (DMSO- $\left.d_{6}, \delta(\mathrm{ppm})\right): 172.26(\mathrm{C}-\mathrm{O}), 164.10(\mathrm{CH}=$ $\mathrm{N}), 149.83\left(\mathrm{CH}=\mathrm{N}_{1,10-p h e n}\right), 60.28\left(\mathrm{~N}-\mathrm{CH}_{2}\right), 28.06\left(\mathrm{CH}_{2}-\mathrm{C}\right)$, 
146.47 (C-N), 107.93-136.69 (Ar C's), mass spectrum (ESI) [M + $\mathrm{H}]^{+}=611.4$.

\subsection{Microbiological analysis}

2.3.1 Strains, media and chemicals. All the strains used in this study are detailed in Table 2, which consist of eight fluconazole (FLC) susceptible including 1 laboratory strain (C. albicans SC5314 and 7 clinical isolates) and 3 FLC resistant clinical isolates. All the clinical Candida strains were collected from Charlotte Maxeke Johannesburg Academic Hospital, Johannesburg, South Africa and were stored in glycerol stocks at $-80{ }^{\circ} \mathrm{C}$ in the department of Clinical Microbiology and Infectious Diseases. All the test strains were isolated from patients under the ethical clearance number M10102 obtained from the Human Research Ethics Committee, University of the Witwatersrand. Prior to experiments, Candida isolates were revived by plating on Sabouraud Dextrose (SD) Agar (Sigma Aldrich, USA), followed by growing single colonies in fresh SD broth. Fluconazole was purchased from Sigma Fluke (USA) and stock solution of $2 \mathrm{mg} \mathrm{mL}^{-1}$ was prepared in sterile distilled water. All other chemicals and media were purchased from Sigma Aldrich and Merck.

\subsubsection{Antifungal susceptibility tests}

2.3.2.1 Determination of minimum inhibitory concentrations. To determine the antifungal activity of the newly synthesized ligand (L) and its four mixed ligand complexes (C1-C4), Minimum Inhibitory Concentrations (MIC) were determined against tested FLC susceptible and FLC resistant $C$. albicans isolates by serial micro-broth dilution method following Clinical and Laboratory Standards Institute (CLSI) recommended guidelines $\mathrm{M} 27-\mathrm{A} 3{ }^{30}$ with modifications. Briefly, microtiter plates were prepared by adding $100 \mu \mathrm{L}$ of SD broth into each of the wells followed by an addition of the test substance at a volume of $100 \mu \mathrm{L}$ in the first column with an initial concentration of $1000 \mu \mathrm{g} \mathrm{mL} \mathrm{m}^{-1}$. The test compounds were serially diluted to yield a final concentration of $250,125,62.5,31.25,16$, $8,4,2,1,0.5,0.25$ and $0.12 \mu \mathrm{g} \mathrm{mL}{ }^{-1}$. The positive control FLC $\left(2000 \mu \mathrm{g} \mathrm{mL} \mathrm{m}^{-1}\right)$ and the negative vehicle control (1\% DMSO) were also included in every set of experiments. Media and culture controls were included to confirm the sterility and viability, respectively. Following serial dilution, test organisms with an approximate final inoculum size of $1 \times 10^{6}$ colony forming units (CFU) per $\mathrm{mL}$, were then added to each well, at a volume of $100 \mu \mathrm{L}$. The microtiter plates were sealed and incubated under $37^{\circ} \mathrm{C}$ for $24 \mathrm{~h}$. After incubation, $400 \mu \mathrm{g} \mathrm{mL}$ of $p$-iodonitrotetrazolium violet solution (INT) was added to each well $(40 \mu \mathrm{L})$. Viable micro-organisms interact with INT to create a colour change from clear to a red-purple colour. Thus, the lowest dilution with no colour change was considered as the MIC for that test compound. All the results were calculated as a mean of the experiments done in duplicate and all the results were expressed in $\mu \mathrm{g} \mathrm{mL}^{-1}$.

2.3.2.2 Growth studies. To further confirm the antifungal activity of the test compounds, growth curve studies were performed as described previously. ${ }^{31}$ Prior to the experiment, all Candida species were sub-cultured and $50 \mu \mathrm{L}\left(1 \times 10^{6} \mathrm{CFU}\right.$
$\mathrm{mL}^{-1}$ ) were added to $50 \mathrm{~mL}$ SD broth. To test the effect of the compounds under study, MIC and $\frac{1}{2}$ MIC of these compounds were added to the respective tubes. All the tubes including control (no test compound) were incubated at $37{ }^{\circ} \mathrm{C}$ with agitation. At a pre-determined time $(0,2,4,6$, and $24 \mathrm{~h}), 2 \mathrm{~mL}$ aliquots were taken and growth was followed turbidometrically at $595 \mathrm{~nm}$ using Shimadzu UV-1800 spectrophotometer. Optical density was recorded for each concentration against time in hours. The growth rate is equivalent to the slope of $\log$ (optical density) versus time during the exponential phase. Average growth rate of untreated versus treated C. albicans were represented as line charts.

2.3.3 Proton efflux measurements. For insight mechanism of antifungal action of the tested compounds, activity of plasma membrane $\mathrm{H}^{+}$-ATPase pump of different $C$. albicans strains was determined by monitoring the acidity of external medium by measuring the $\mathrm{pH}$, as described earlier. ${ }^{32}$ Briefly, one laboratory strain along with one FLC susceptible and one FLC resistant isolates were grown in SD media and incubated at $37^{\circ} \mathrm{C}$ until the cells reach mid-log phase (6-8 h). After incubation cells were harvested by centrifugation and washed twice with sterile distilled water. $100 \mathrm{mg}$ of wet weighed cells were then suspended in $5 \mathrm{~mL}$ of buffer containing $0.1 \mathrm{M} \mathrm{KCl}$ and $0.1 \mathrm{M} \mathrm{CaCl}_{2}$. Immediately after the addition of cells, initial $\mathrm{pH}$ of the suspension was set at $\mathrm{pH} 7.0$ using either $0.01 \mathrm{M} \mathrm{NaOH}$ or $\mathrm{HCl}$. For the next 10 minutes, the $\mathrm{pH}$ of the solution was kept at 7.0 using $0.01 \mathrm{M} \mathrm{NaOH}$ and the volume of the $0.01 \mathrm{M} \mathrm{NaOH}$ consumed was calculated. To determine the effect of test compounds, $100 \mu \mathrm{L}$ of the different stock compounds were added to achieve desired MIC values in the buffer and $\mathrm{pH}$ was kept constant at 7.0 and the volume of $0.01 \mathrm{M} \mathrm{NaOH}$ consumed was calculated. For glucose stimulation experiments, $100 \mu \mathrm{L}$ of glucose was added to achieve a final concentration of $5 \mathrm{mM}$ to both treated and untreated sets. The rate of proton efflux will be calculated using the formula:

$$
\text { Rate of } \mathrm{H}^{+} \text {efflux }=\frac{\text { volume of } \mathrm{NaOH} \times 10^{-11} \mathrm{~mol}}{\mathrm{mg} \text { cells } \times \text { time }}
$$

2.3.4 Measurements of intracellular $\mathrm{pH}$ (pHi). To further confirm the effect of test compounds on $\mathrm{H}^{+}$ATPase pump, $\mathrm{pHi}$ of $C$. albicans strains was measured as described previously. ${ }^{32}$ pHi was quantified to determine whether the cells with dysfunctional $\mathrm{H}^{+}$-ATPase activity maintains the internal $\mathrm{pH}$ of 6.5-6.9 as compared to cells with functional $\mathrm{H}^{+}$ATPase activity. $0.1 \mathrm{~g}$ of mid-log phase grown C. albicans cells were suspended in $5 \mathrm{~mL}$ solution containing $0.1 \mathrm{M} \mathrm{KCl}$ and $0.1 \mathrm{mM} \mathrm{CaCl}_{2}$. To check the effect all the test compounds were separately added into the suspension at their respective MIC values and $\mathrm{pH}$ was adjusted to 7.0 using either $0.01 \mathrm{M} \mathrm{NaOH}$ or $\mathrm{HCl}$. The suspensions were then incubated at $37^{\circ} \mathrm{C}$ for 30 minutes with constant shaking at $200 \mathrm{rpm}$. After incubation $\mathrm{pH}$ was again set to 7.0 and $20 \mu \mathrm{M}$ nystatin was added to all the cell suspensions followed by reincubation at $37^{\circ} \mathrm{C}$ for $1 \mathrm{~h}$. After incubation, the change in $\mathrm{pH}$ level of the cell suspensions were measured and the value of the external $\mathrm{pH}$ at which nystatin permeabilization induced no further shift was taken as an estimate of pHi. In every set of 
experiment untreated cells were included as negative control and pHi was measured directly from the suspensions in triplicates and the mean of the $\mathrm{pH}$ recorded was used as the final pHi.

\section{Results and discussion}

\subsection{Chemistry}

The mixed ligand complexes with an indole pendent were prepared by reacting equimolar amounts of the ligand, obtained by condensation of tryptamine with 2-hydroxynapthaldehyde and the corresponding metal salts, and 1,10phenanthroline in presence of triethylamine. All the resulting metal complexes were neutral, colored, air stable and remarkably soluble in DMF and DMSO. The ligand and metal complexes were analyzed using various physico-chemical properties like melting point, yield, color, elemental analysis and conductivity measurements as reported in Table 1 . The molar conductivity of the complexes was carried out using DMSO $\left(10^{-3} \mathrm{M}\right)$ at room temperature. The results obtained were in the range of $18-27 \Omega^{-1} \mathrm{~cm}^{2} \mathrm{~m}^{-1}$ which indicated their nonelectrolytic nature. All the compounds were thoroughly characterized using various spectral techniques like FT-IR, NMR and mass spectrometry. The analytical data of the ligand and metal complexes were in good agreement with their proposed formula. The ESI MS of the Schiff base ligand (L) and complexes (C1-C4) in $\mathrm{MeOH}$ were recorded and found in good agreement with the calculated $m / z$ values (Fig. S1-S5 $\dagger$ ). The FT-IR spectrum of the Schiff base ligand ( $\mathbf{L}$ ) displayed a strong band at $1618 \mathrm{~cm}^{-1}$ corresponding to $\nu(\mathrm{CH}=\mathrm{N})$ of azomethine group. In complexes the azomethine $(-\mathrm{CH}=\mathrm{N}-$ ) band got shifted to lower frequencies due to the withdrawal of electron density from the nitrogen atom indicating the coordination of $\mathrm{CH}=\mathrm{N}$ group to metal ions (Fig. 1)..$^{33}$ The band present in Schiff base (L) at $3152 \mathrm{~cm}^{-1}$ attributed to -OH stretching vibrations was absent in complexes due to deprotonation upon complexation. ${ }^{34}$ In complexes (C1-C4) the broad band at $3505-3510 \mathrm{~cm}^{-1}$ was attributed to $\nu(\mathrm{OH})$ of the coordinated water present in these complexes. $^{18}$ In 1,10-phenanthroline the band at $1633 \mathrm{~cm}^{-1}$ corresponds to pyridyl nitrogen stretching vibration and in complexes this band was shifted to lower frequencies which clearly indicate the coordination of two nitrogen atoms to metal ions upon complexation. The low frequency region of the spectra in complexes showed the presence of new bands in the region of $476-480 \mathrm{~cm}^{-1}$ and $520-530 \mathrm{~cm}^{-1}$ assigned to $\nu(\mathrm{M}-\mathrm{N})$

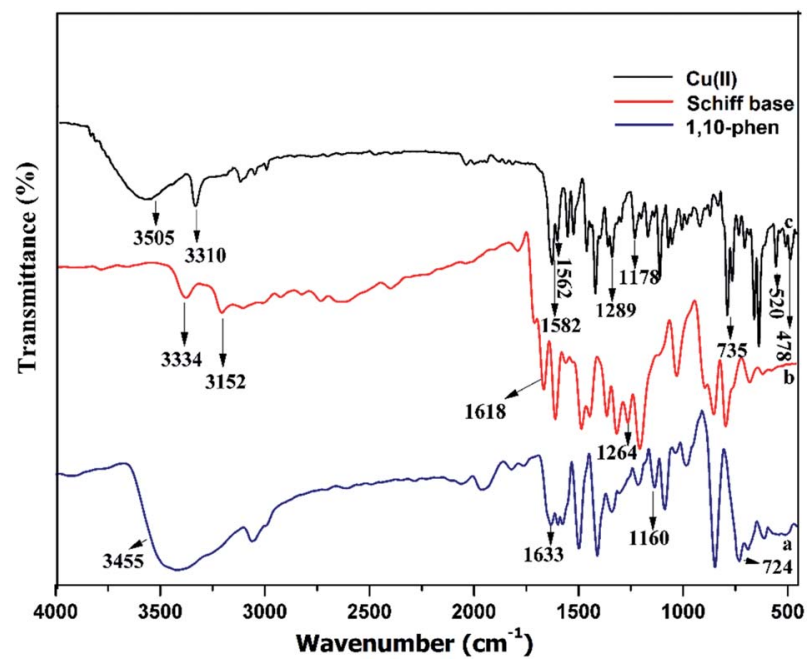

Fig. 1 FT-IR spectra of (a) 1,10-phenanthroline, (b) Schiff base (L) and (c) Cu(॥) complex (C1).

and $\nu(\mathrm{M}-\mathrm{O})$ stretching vibrations respectively (Fig. S6-S8†). ${ }^{35} \mathrm{In}$ addition, further evidence for the formation of Schiff base ( $\mathbf{L})$ and C4 complex was obtained from the NMR spectra. The attained ${ }^{1} \mathrm{H}$ and ${ }^{13} \mathrm{C}$ NMR values of $\mathbf{C 4}$ complex were compared with the corresponding ligand and were in good agreement with the proposed structure of the $\mathbf{C 4}$ complex. The ${ }^{1} \mathrm{H}$ and ${ }^{13} \mathrm{C}$ NMR spectra of the ligand and $\mathbf{C} 4$ complex have been given in ESI. $\dagger$ Complexes C1, C2 and $\mathbf{C} 3$ did not furnish good and presentable NMR spectra due to the paramagnetic nature of the complexes.

\subsection{Biological studies}

3.2.1 Minimum inhibitory concentration. The antifungal activity of the ligand (L) and its metal complexes (C1-C4), C4 was evaluated by determining their MIC values. All the MIC results are summarized in Table 2. Evaluation of MIC depicts that among the ligand (L) and its four complexes (C1-C4), C3 showed highest inhibitory activity while as $\mathbf{L}$ showed the least inhibitory activity against all the tested strains. The MIC values for $\mathbf{C} 3$ ranges from $1-0.25 \mu \mathrm{g} \mathrm{mL}^{-1}$ while as for $\mathrm{L}$ these values range from $125-500 \mu \mathrm{g} \mathrm{mL} \mathrm{mL}^{-1}$. Based on the MIC values, order of potency of the test compounds was $\mathbf{C} 3>\mathbf{C} 2>\mathbf{C} 1 \geq \mathbf{C} 4>\mathbf{L}$. Isolates having an MIC values $<8 \mu \mathrm{g} \mathrm{mL}^{-1}$ for FLC were considered FLC susceptible while as the isolates having MIC $\geq$ $8 \mu \mathrm{g} \mathrm{mL}{ }^{-1}$ were categorized as FLC resistant, following the CLSI Interpretive Guidelines for In vitro Susceptibility Testing of

Table 1 Physico-chemical properties of ligand (L) and complexes (C1-C4)

\begin{tabular}{|c|c|c|c|c|c|c|c|}
\hline Compound & Color & Mol. formula & Mol. wt & $(\mathrm{m} / \mathrm{z})$ ratio & Yield (\%) & $\Lambda_{\mathrm{m}}\left(\Omega^{-1} \mathrm{~cm}^{2} \mathrm{~mol}^{-1}\right)$ & $\operatorname{Mp}\left({ }^{\circ} \mathrm{C}\right)$ \\
\hline $\mathbf{L}$ & Yellow & $\mathrm{C}_{21} \mathrm{H}_{17} \mathrm{~N}_{2} \mathrm{O}$ & 313 & 315 & 82 & - & 192 \\
\hline C1 & Yellow green & {$\left[\mathrm{C}_{33} \mathrm{H}_{27} \mathrm{ClCuN}_{4} \mathrm{O}_{2}\right]$} & 609.1 & 609.5 & 68 & 27 & 252 \\
\hline C3 & Reddish brown & {$\left[\mathrm{C}_{33} \mathrm{H}_{27} \mathrm{ClN}_{4} \mathrm{NiO}_{2}\right]$} & 604.1 & 605.5 & 69 & 18 & 220 \\
\hline $\mathbf{C 4}$ & Beige & {$\left[\mathrm{C}_{33} \mathrm{H}_{27} \mathrm{ClN}_{4} \mathrm{O}_{2} \mathrm{Zn}\right]$} & 610.1 & 611.4 & 70 & 20 & 222 \\
\hline
\end{tabular}


Table 2 Minimum inhibitory concentrations $\left(\mu \mathrm{g} \mathrm{mL}^{-1}\right.$ ) of the ligand $(\mathrm{L})$ and its complexes (C1-C4) against FLC susceptible and resistant $C$. albicans isolates

\begin{tabular}{llllllll}
\hline & \multicolumn{7}{c}{$\begin{array}{l}\text { Minimum inhibitory concentrations } \\
\left(\mu \mathrm{g} \mathrm{mL} \mathrm{mL}^{-1}\right)\end{array}$} \\
\cline { 2 - 8 } Strains & & $\mathbf{L}$ & $\mathbf{C 1}$ & $\mathbf{C 2}$ & $\mathbf{C 3}$ & $\mathbf{C 4}$ & $\mathrm{FLC}$ \\
\hline C. albicans SC5314 & & 250 & 62.5 & 1 & 0.25 & 62.5 & 0.25 \\
FLC susceptible strains & 4175 & 500 & 250 & 0.50 & 0.50 & 250 & 0.12 \\
& 4179 & 500 & 250 & 2 & 0.50 & 250 & 0.25 \\
& 4180 & 250 & 62.5 & 2 & 0.50 & 125 & 0.25 \\
& 4251 & 125 & 125 & 1 & 0.25 & 125 & 0.25 \\
& 4554 & 500 & 250 & 2 & 0.50 & 250 & 0.25 \\
& 4563 & 125 & 62.5 & 0.50 & 0.25 & 62.5 & 0.25 \\
& 4576 & 250 & 250 & 2 & 0.50 & 250 & 0.25 \\
& 4085 & 250 & 125 & 4 & 0.5 & 125 & 16 \\
& 4122 & 500 & 250 & 8 & 1 & 250 & 32 \\
& 4135 & 500 & 250 & 8 & 0.5 & 250 & 32
\end{tabular}

Candida species. ${ }^{36}$ Furthermore, all the test compounds were prepared to different concentrations using 1\% DMSO and therefore DMSO was used as negative vehicle control and was observed to have no inhibitory activity against any of the tested isolates. The MIC data revealed that the structural changes from ligand to its metal complexes resulted in marked enhancement in their potency as antifungal agents.

3.2.2 Growth curve analysis. To further support the MIC results and to study the influence of the test compounds on $C$. albicans, cells of strain SC5314, 4175 and 4085 were grown in presence of MIC and $\frac{1}{2} \mathrm{MIC}$ values of all the test compounds and growth curves were determined. All the untreated control cells depict normal growth pattern, with a lag phase of 4 hours, exponential phase of 8-10 hours before attaining the stationary phase. At $\frac{1}{2} \mathrm{MIC}$ values, test compounds resulted in the reduction of cell growth at varying levels without being fungicidal (Fig. 2). However, at MIC values of these compounds, almost complete growth inhibition was observed which can be represented by a flat line in comparison to the control (Fig. 2). It was also observed at sub-MIC values of these compounds; log phase has been delayed by 2 to 4 hours. As expected, FLC at a concentration of $2 \mu \mathrm{g} \mathrm{mL} \mathrm{m}^{-1}$ drastically inhibited growth in both the tested FLC susceptible isolates while as in FLC resistant isolate, growth has been suppressed but not inhibited.

3.2.3 Proton efflux measurements. Varying MIC values of these test compounds encouraged us to determine their mode of antifungal action. Schiff base compounds and their metal complexes are known to interact with the proteins and nucleic acids. $^{37,38}$ In addition, quick antifungal action of these compounds suggests that there may be a cellular target(s) accessible to the compound externally. With this background, we tested the activity of $C$. albicans strains for their ability to pump intracellular protons to the external medium in the presence of all the tested compounds under study. Table S1 $\dagger$ gives relative rates of $\mathrm{H}^{+}$-efflux by C. albicans strains in presence of the ligand (L) and complexes (C1-C4) at their respective MIC values. $\mathrm{H}^{+}$-efflux inhibition in standard C. albicans SC5314
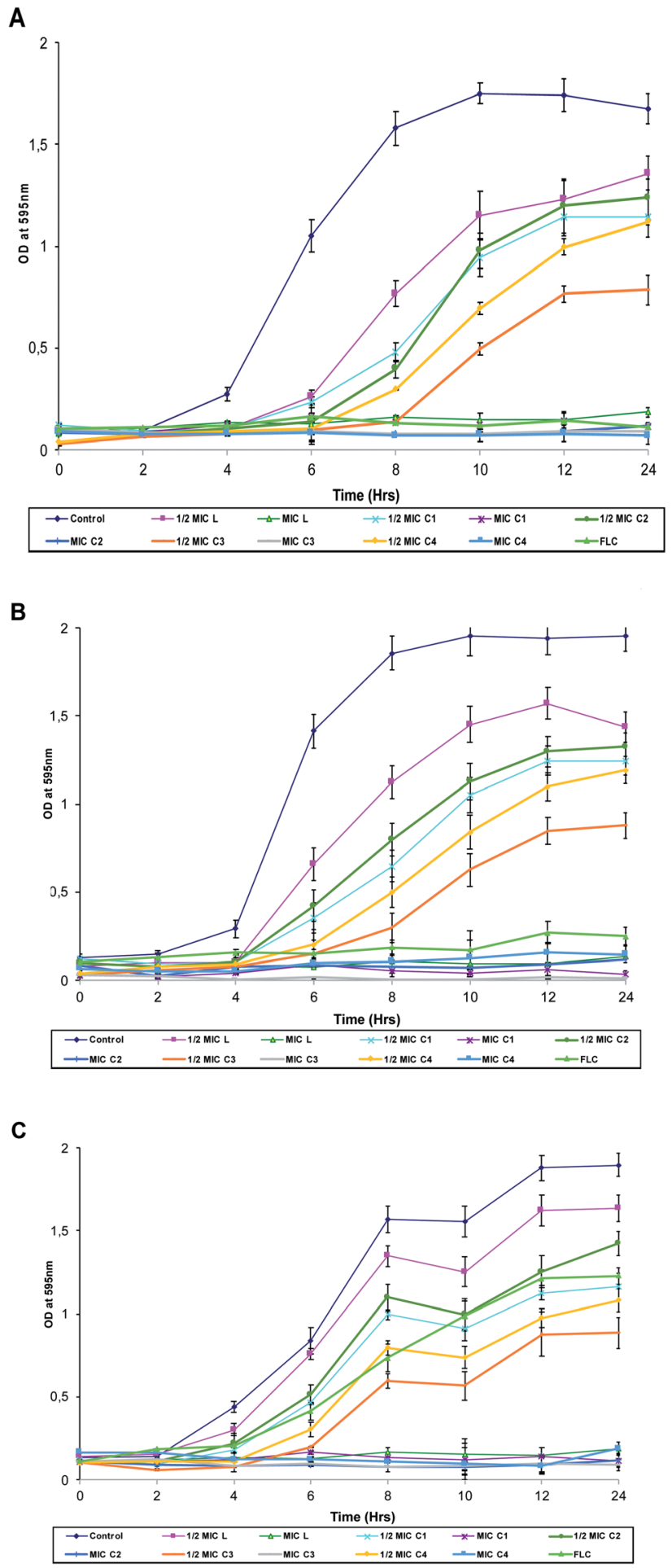

Fig. 2 Effect of Schiff base ligand (L) and its metal complexes (C1, C2, $\mathrm{C} 3$ and C4) at their MIC and $\frac{1}{2} \mathrm{MIC}$ values against C. albicans SC5314 (A), C. albicans 4175 (B) and C. albicans 4085 (C). Growth curves between absorbance at $595 \mathrm{~nm}$ and time (h) showed complete growth inhibition at MIC values of these compounds.

strain, with respect to control, ranges from $26-67 \%$ in absence of glucose, whereas these figures range from $15-51 \%$ when lab strain was treated with compounds in presence of glucose. In 
clinical strains, $\mathrm{H}^{+}$-efflux inhibition ranged from $19-72 \%$ and $11-67 \%$ in absence and presence of glucose, respectively. Interestingly, $5 \mathrm{mM}$ glucose stimulated $\mathrm{H}^{+}$-efflux in all the strains by 2 -fold, however all the test compounds inhibited this efflux with varying degrees. It can be presumed that the enzyme may exist in a different conformational state in presence and absence of glucose. The $\mathrm{H}^{+}$-efflux results directly correlate with the antifungal activities of these test compounds with most prominent $\mathrm{H}^{+}$-efflux inhibitory activity shown by C3 complex where as $\mathbf{L}$ showed the least inhibition of $\mathrm{H}^{+}$-efflux. Interestingly FLC at $2 \mu \mathrm{g} \mathrm{mL}{ }^{-1}$ showed least inhibition on $\mathrm{H}^{+}$-efflux by either of the $C$. albicans species tested. FLC is known to interact with the sterol components of the membrane, however, have no significant effect on $\mathrm{H}^{+}$-ATPase pump. These results confirmed that interaction of any compound with plasma membrane is insufficient to inhibit the activity of the $\mathrm{H}^{+}$-ATPase pump and therefore the compounds under study may be directly binding to this pump and thereby inhibiting the $\mathrm{H}^{+}$-efflux from Candida cells. The $\mathrm{H}^{+}$translocating ATPase mediated fungicidal effects of the metal complexes under study suggest that plasma membrane $\mathrm{H}^{+}$-ATPase targeting compounds could be developed as cell surface antifungal targets. The higher antifungal efficacy of the C3 complex compared to the otherwise structurally similar complexes $\mathbf{C 1}, \mathbf{C} 2$ and $\mathbf{C 4}$ could be due to the difference in the redox potential of the metal ions or it could be due to the difference in the exchange of the co-ligands or binding with the biological target. Rapidity of action, low MIC values, and lethal effect demands more insight studies into all other possible mechanisms of these metal complexes.

3.2.4 Measurement of intracellular $\mathbf{~ p H}$. The $\mathrm{pHi}$ of Candida cells is maintained between $6.0-7.5$ by plasma membrane $\mathrm{H}^{+}$ATPase activity. The pHi of FLC susceptible and FLC resistant $C$. albicans strains was measured following the exposure to test compounds at MIC. All the test compounds decreased pHi of $C$. albicans cells compared to the untreated cells at varying levels

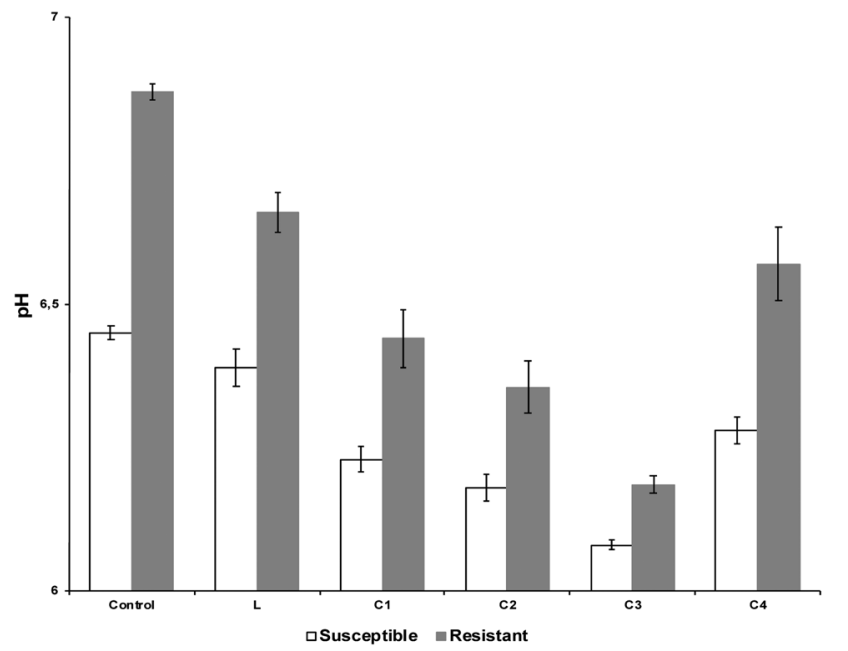

Fig. 3 Intracellular $\mathrm{pH}$ of FLC susceptible and resistant strains treated with the test compounds at MIC values. The $\mathrm{pH}$ of treated cells decreased towards a neutral $\mathrm{pH}$ in comparison to untreated control cells.
(Fig. 3). As expected, untreated control cells maintain the pHi of 6.45 (FLC susceptible) and 6.87 (FLC resistant). In treated cells, pHi sharply decreased from 6.30-6.081 in FLC susceptible strains whereas these figures decreased from 6.66-6.186 in FLC resistant strains. The pHi in FLC resistant cells are comparatively acidic than FLC susceptible cells, however, the tested compounds declined $\mathrm{pHi}$ in both the types of cells. The decrease in pHi post treatment with the tested compounds further confirmed that these compounds target plasma membrane $\mathrm{H}^{+}$-ATPase pump rather than disturbing electron transport chain and other V-type proton pumps. However, further studies are required to prove these claims.

\section{Conclusions}

A series of metal complexes obtained from a Schiff base bidentate ligand and 1,10-phenenthroline as a co-ligand was obtained, structurally characterized and evaluated for their antifungal potential. Based on various physical and spectroscopic techniques octahedral geometry was assigned to C2, C3 and $\mathbf{C 4}$ complexes while as distorted octahedral geometry was assigned to $\mathbf{C} 1$ complex. Evaluation of the antifungal potential against both resistant and susceptible Candida albicans showed that these complexes have a great potential to lead as antifungal agents; C3 being the most active against the resistant strains. The collection of results presented herein are especially useful in antifungal drug development targeting proton pumping ATPase pump. The results of this study revealed that these complexes have a targeted activity, although, other modes of action cannot be ruled out because metal complexes are known to target multiple pathways to evade drug resistance.

\section{Conflicts of interest}

The authors declare that they have no competing interests.

\section{Acknowledgements}

The author OAD is thankful to University Grants Commission (UGC), Government of India for financial assistance through Central University PhD Students Fellowship. AA acknowledges financial support from University Research Committee Grant for 2019 - Friedel Sellschop Award (Grant No: AZMD019).

\section{References}

1 N. Wiederhold, Infect. Drug Resist., 2017, 10, 249-259.

2 M. C. Fisher, N. J. Hawkins, D. Sanglard and S. J. Gurr, Science, 2018, 360, 739-742.

3 D. W. Denning, Philos. Trans. R. Soc., B, 2016, 371, 20150468.

4 M. A. Pfaller, D. J. Diekema, D. L. Gibbs, V. A. Newell, J. F. Meis, I. M. Gould, W. Fu, A. L. Colombo and E. Rodriguez-Noriega, J. Clin. Microbiol., 2007, 45, 17351745 .

5 K. D. Mjos and C. Orvig, Chem. Rev., 2014, 114, 4540-4563.

6 Y. C. Ong, S. Roy, P. C. Andrews and G. Gasser, Chem. Rev., 2019, 119, 730-796. 
7 M. Zaki, F. Arjmand and S. Tabassum, Inorg. Chim. Acta, 2016, 444, 1-22.

8 K. J. Kilpin and P. J. Dyson, Chem. Sci., 2013, 4, 1410.

9 S. A. Hosseini-Yazdi, P. Samadzadeh-Aghdam, A. Mirzaahmadi, A. A. Khandar, G. Mahmoudi, M. Ruck, T. Doert, S. S. Balula and L. Cunha-Silva, Polyhedron, 2014, 80, 41-46.

10 L. Li, Q. Guo, J. Dong, T. Xu and J. Li, J. Photochem. Photobiol., B, 2013, 125, 56-62.

11 N. Shahabadi, S. Kashanian and F. Darabi, Eur. J. Med. Chem., 2010, 45, 4239-4245.

12 S. Kathiresan, S. Mugesh, J. Annaraj and M. Murugan, New J. Chem., 2017, 41, 1267-1283.

13 A. Palanimurugan and A. Kulandaisamy, J. Organomet. Chem., 2018, 861, 263-274.

14 Z. Travnicek, M. Malon, Z. Sindelar, K. Dolezal, J. Rolcík, V. Krystof, M. Strnad and J. Marek, J. Inorg. Biochem., 2001, 84, 23-32.

15 P. Tyagi, M. Tyagi, S. Agrawal, S. Chandra, H. Ojha and M. Pathak, Spectrochim. Acta, Part A, 2017, 171, 246-257.

16 M. A. Malik, O. A. Dar, P. Gull, M. Y. Wani and A. A. Hashmi, MedChemComm, 2018, 9, 409-436.

17 I. M. Mustafa, M. A. Hapipah, M. A. Abdulla and T. R. Ward, Polyhedron, 2009, 28, 3993-3998.

18 A. A. S. Al-Hamdani and W. Al Zoubi, Spectrochim. Acta, Part A, 2015, 137, 75-89.

19 M. Ibrahim, H. Ali, M. Abdullah and P. Hassandarvish, Molecules, 2012, 17, 12449-12459.

20 J. Ki, A. Mukherjee, S. Rangasamy, B. Purushothaman and J. M. Song, RSC Adv., 2016, 6, 57530-57539.

21 C. M. Sharaby, M. F. Amine and A. A. Hamed, J. Mol. Struct., 2017, 1134, 208-216.

22 J. Dutta, S. Datta, D. Kumar Seth and S. Bhattacharya, RSC Adv., 2012, 2, 11751.
23 Z. A. Siddiqi, M. Khalid, S. Kumar, M. Shahid and S. Noor, Eur. J. Med. Chem., 2010, 45, 264-269.

24 Y. Prashanthi, K. Kiranmai, Ira, S. K. kumar, V. kumar Chityala and Shivaraj, Bioinorg. Chem. Appl., 2012, 2012, 1-8.

25 M. Aljahdali and A. A. EL-Sherif, Inorg. Chim. Acta, 2013, 407, 58-68.

26 S. I. Mostafa, Transition Met. Chem., 2007, 32, 769-775.

27 H. F. Abd El-Halim, G. G. Mohamed and E. A. M. Khalil, J. Mol. Struct., 2017, 1146, 153-163.

28 W. H. Mahmoud, G. G. Mohamed and S. Y. A. Mohamedin, J. Therm. Anal. Calorim., 2017, 130, 2167-2184.

29 S. Baskaran, M. Murali Krishnan and M. N. Arumugham, Inorg. Nano-Met. Chem., 2017, 47, 269-277.

30 CLSI, Clinical and Laboratory Standards Institute Reference method for broth dilution antifungal susceptibility testing of yeast, Approved Standard M27-A3, Wayne, PA, USA, 2008, p. 40.

31 A. Khan, A. Ahmad, N. Manzoor and L. A. Khan, Nat. Prod. Commun., 2010, 5, 345-349.

32 A. Ahmad, A. Khan, S. Yousuf, L. A. Khan and N. Manzoor, Fitoterapia, 2010, 81, 1157-1162.

33 M. A. Malik, M. K. Raza, O. A. Dar, Amadudin, M. Abid, M. Y. Wani, A. S. Al-Bogami and A. A. Hashmi, Bioorg. Chem., 2019, 87, 773-782.

34 M. M. Abo-Aly, A. M. Salem, M. A. Sayed and A. A. Abdel Aziz, Spectrochim. Acta, Part A, 2015, 136, 993-1000.

35 W. H. Mahmoud, N. F. Mahmoud and G. G. Mohamed, J. Organomet. Chem., 2017, 848, 288-301.

36 Y. Jia and J. Li, Chem. Rev., 2015, 115, 1597-1621.

37 Clinical and Laboratory Standards Institute (CLSI), Reference method for broth dilution antifungal susceptibility testing of yeasts, Wayne, 2012, document M27-S4.

38 Z. Shokohi-pour, H. Chiniforoshan, A. A. Momtazi-borojeni and B. Notash, J. Photochem. Photobiol., B, 2016, 162, 34-44. 